\title{
Design and Development of Mosquito Repellent Formulation Containing Carom Seed
}

Nikam Mangesh Maruti*, More V.V.

SVERI's College of Pharmacy Pandharpur, Maharashtra, India

\begin{abstract}
Article Info
Volume 7, Issue 5

Page Number: 88-94

Publication Issue :
\end{abstract}

September-October-2020

\section{Article History}

Accepted : 16 Sep 2020

Published : 23 Sep 2020

\section{ABSTRACT}

Mosquito bites can give an unpleasant feeling and may transmit the vector disease such as dengue or malaria to humankind. Mosquitoes are attracted to human blood containing protein to develop their eggs, biting human to another human, thereby transmitting the vector disease to human. Topical mosquito repellent gel was prepared with different concentration of extracted oil from carom seed all the formulation showed satisfied result with regular evaluation parameters like spreadability, washability, mosquito repellent activity, irritancy test. The formulation containing 7.5\% of Carom seed oil extract showed repellent activity up to $80 \%$ these results are encouraging and promising. At last it was concluded that Carom seed oil extract has potential of mosquito repellent and can be converted into a marketed formulation like essence stick, repellent Gel etc. ${ }^{[1]}$

Keywords : Mosquito Repellents, Carom Seed Oil, Skin Sensitivity, Trachycpermum Ammi, Screen Cage Method.

\section{INTRODUCTION}

A mosquito repellent doesn't actually kill mosquitoes. Repellents work by making people less attractive to mosquitoes, so they're less likely to bite you. The Environmental Protection Agency (EPA) says mosquito repellents that contain natural oils are safe for adults and children over the age of 2 months, when used correctly. Many repellents are nowadays available which can easily fend off the mosquitoes but are not good for the health as it contains a harmful chemical called DEET. It is fine to use a natural repellent which can make you unattractive in the eyes of mosquitoes. The use of naturals oils as an insect repellent is one of the wisest choices $u$ can make. The biggest advantages of using only natural oils is that they are non-toxic and safe with no side effect.

Trachyspermum ammi is a native of Egypt and is cultivated in Iraq, Iran, Afghanistan, Pakistan, and India. In India, it is cultivated in Madhyapardesh, Uttarpardesh, Gujarat, Rajasthan, Maharashtra, Bihar and West Bengal. Trachyspermum ammi L. belonging 
to family Apiaceae is a highly valued medicinally important seed spice. The roots are diuretic in nature and the seeds possess excellent aphrodisiac properties. The seeds contain $2-4.4 \%$ brown colored oil known as Ajwain oil. The main component of this oil is thymol, which is used in insecticide. the carom seeds are also a popular addition to borders and vegetable gardens. According to NYBG, not only can they keep away mosquitoes, but they also dissuade aphids, thrips, whiteflies, Mexican bean beetles, squash bugs, and tomato hornworms. Thus, a research will be conduct to study on formulation of natural mosquito repellent solution using extraction process for Carom seeds. Thymol has been extracted from Carom seed using at various extraction conditions such as different temperature, extraction time and volume of solvent. The summary of this attempt on claiming and efficacy of plant-based repellents are suggested for further drug development program. These plant seeds may represent an alternative in formulating potent and affordable products in the control of mosquitoes. ${ }^{[2]}$

\section{MATERIAL \& METHOD:}

Table No.1. List of instruments

\begin{tabular}{|c|c|c|}
\hline $\begin{array}{c}\text { Sr. } \\
\text { No. }\end{array}$ & Instrument Name & Make \\
\hline $\mathbf{1}$ & GC-MS & $\begin{array}{c}\text { QP2010 Plus, } \\
\text { Shimadzu, Japan }\end{array}$ \\
\hline $\mathbf{2}$ & FTIR & Bruker \\
\hline $\mathbf{3}$ & pH meter & Labtronics LT - 11 \\
\hline $\mathbf{4}$ & Clevenger apparatus & Borosil lab \\
\hline
\end{tabular}

\section{Extraction of Carom seed oil:}

\section{Hydro-distillation using Clevenger's method:}

The plant parts of Carom seed oil i.e. flower (fresh and dry) were subjected to hydro-distillation using a Clevenger's apparatus. The collection of oil started. after a heating time of about 40 minutes and was continued till no more essential oil was obtained after 5-6 hours. After the distillation process was complete, the volatile essential oils were removed from the top of the hydrosol and dried over anhydrous sodium sulphate ( $\mathrm{Na} 2 \mathrm{SO} 4)$ and stored in small sealed tubes at low temperature for preliminary screening of phytometabolites, qualitative screening by FT-IR and quantitative GC-MS analysis. ${ }^{[2]}$

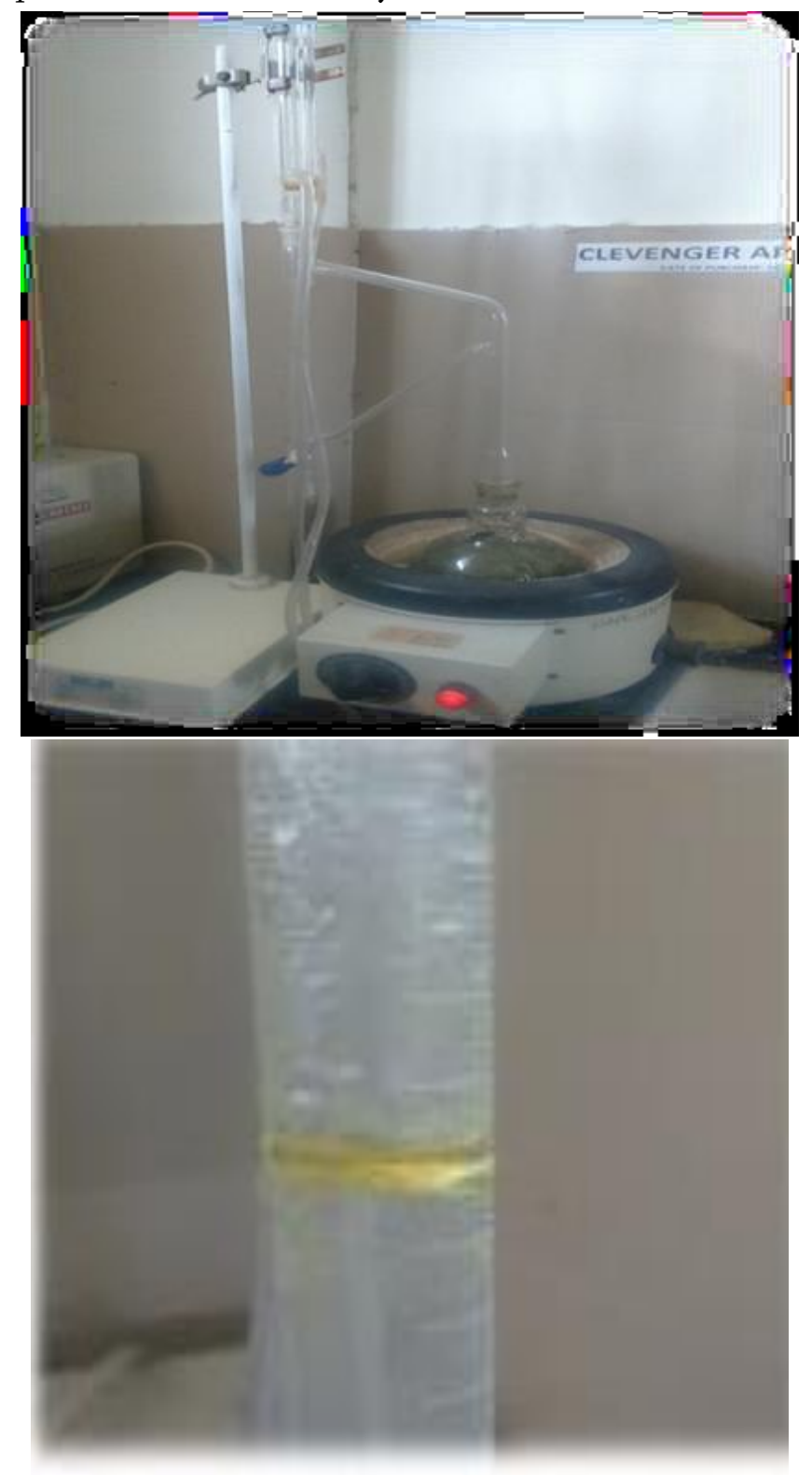

Fig No.1 Oil extraction from fresh carom seed by Clevenger method 


\section{Preparation of Mosquito repellent product:}

\section{Formulation of herbal mosquito repellent Cream.}

Mosquito repellent cream: - An aqueous cream (oil in water type) was prepared by emulsifying the essential oils in water with an emulsifying wax. The formula for the insect repellent cream is as follows:

Table no.2 Formulation concentration

\begin{tabular}{|l|c|c|c|}
\hline \multicolumn{1}{|c|}{ Ingredient } & F1 & F2 & F3 \\
\hline $\begin{array}{l}\text { Carom seed } \\
\text { oil }\end{array}$ & $2.5 \%$ & $5 \%$ & $7.5 \%$ \\
\hline Cetyl alcohol & $2 \%$ & $2 \%$ & $2 \%$ \\
\hline Lanolin & $1 \%$ & $1 \%$ & $1 \%$ \\
\hline Mineral oil & $2 \%$ & $2 \%$ & $2 \%$ \\
\hline Stearic acid & $15 \%$ & $15 \%$ & $15 \%$ \\
\hline Glycerine & $10 \%$ & $10 \%$ & $10 \%$ \\
\hline $\begin{array}{l}\text { Pot. } \\
\text { Hydroxide }\end{array}$ & $1 \%$ & $1 \%$ & $1 \%$ \\
\hline Water & Q.S. & Q.S. & Q.S. \\
\hline
\end{tabular}

\section{Procedure:}

The oil in water type cream was prepared by incorporating lanolin, stearic acid, cetyl alcohol, mineral oil, propyl paraben, etc. in the oil phase and Glycerine, potassium hydroxide, etc. in water phase respectively. Both oil and aqueous phases were heated to $75^{\circ} \mathrm{c}$. After heating, the oil phase was added into the aqueous phase with continuous stirring until the homogenous cream was formed. After complete emulsification, essentials oils were added when the temperature dropped to $55^{\circ} \mathrm{C} \pm 60^{\circ} \mathrm{C}$. [5]

\section{Evaluation:}

\section{Evaluation of extracted oil;}

\section{Gas Chromatography- Mass Spectroscopy (GC-MS)}

Carom seed oil was analyzed using GC-MS (QP2010 Plus, Shimadzu, Japan), equipped with an Rtx-5 MS capillary column $(30.0 \mathrm{~m}$ x $0.20 .25 \mathrm{~mm}$ i.d., $0.25 \mu \mathrm{m}$ film thickness) for the separation of its components. The injector was maintained at $260^{\circ} \mathrm{C}$ and operated in split injection mode (split ratio 50) with the split valve closed for one min and injection volume was 6 $\mu \mathrm{L}$. Helium gas was used as the carrier gas at a constant pressure of $69 \mathrm{kPa}$. The column oven was initially maintained at $50^{\circ} \mathrm{C}$ for two min, raised to $210^{\circ} \mathrm{C}$ at $3^{\circ} \mathrm{C} / \mathrm{min}$, then to $280^{\circ} \mathrm{C}$ at $10^{\circ} \mathrm{C} / \mathrm{min}$. The interface temperature was $270^{\circ} \mathrm{C}$ and the ionization mode was electron impact $(70 \mathrm{eV})$. The mass selective detector was operated in the scan mode between 40 and $650 \mathrm{~m} / \mathrm{z}$. Data acquisition was started $3.0 \mathrm{~min}$ after injection. MS parameters used were; Ionization Voltage (EI) $70 \mathrm{eV}$, peak width 2s, mass.

\section{Fourier Transform Infra-red Spectroscopy (F.T.I.R):}

IR spectroscopy of Carom seed oil was done by using FT-IR spectrophotometer (JASCO FTIR-410). The spectra were scanned over wavelength region of 4000 to $400 \mathrm{~cm}-1$ at resolution of $4 \mathrm{~cm}-1$ the procedure consisted of dispersing sample of $\mathrm{KBr}$ and compressing into disc by applying of pressure consisted of 5 tons for 5 minutes in hydraulic press. The oil was placed in light path and the spectrum was obtained.

\section{Evaluation of formulation:}

\section{Evaluation of herbal mosquito repellent Cream:}

\section{Primary test:}

a. Colour: - Colour of cream was observed visually.

b. Odour: - The odour of herbal cream was observed. 
2. $\mathrm{pH}$ : The $\mathrm{pH}$ of various formulations was determined by using digital $\mathrm{pH}$ meter. About $1 \mathrm{~g}$ of the cream was weighed and dissolved in $100 \mathrm{ml}$ of distilled water and stored for two hours. The measurement of $\mathrm{pH}$ of each formulation was done in triplicate and average values were calculated.

3. Spreadability: The Spreadability was expressed in terms of time in seconds taken by two slides to slip off from the cream, placed in between the slides, under certain load. Lesser the time taken for separation of the two slides, better the Spreadability. Two sets of glass slides of standard dimensions were taken. The herbal cream formulation was placed over one of the slides. The other slide was placed on the top of the formulation, such that the cream was sandwiched between the two slides weight was placed upon the upper slides so that the cream between the two slides was pressed uniformly to form a thin layer. The weight was removed and the excess of formulation adhering to the slides was scrapped off. The upper slide allowed slipping off freely by the force of weight tied to it. The time taken for the upper slide was noted.

\section{Spreadability $=\mathrm{m} \times \mathrm{l} / \mathrm{t}$}

Were;

$\mathrm{m}=$ weight tied to the upper slide $(30 \mathrm{~g})$

$l=$ length of glass slide $(5 \mathrm{~cm})$

$\mathrm{t}=$ time taken in seconds.

1. Washability: Wash ability A small amount of cream applied on hand \& washed under running tap water.

2. Extrudability: The extrudability of the prepared formulation was determined by first filling the cream (100 g) into a capped collapsible aluminum tube and sealed by using manual ointment sealing machine. The tubes (containing different formulations) were placed in between two slides and properly clamped. It was followed by placing $500 \mathrm{~g}$ weight over the slides and ultimately opening the cap where the extruded ribbon length was noted after $10 \mathrm{~min}$.

3. Determination of viscosity: Brookfield Viscometer (Model RVT) with helipath stand was used for rheological studies. The sample (50 g) was placed in a beaker and was allowed to equilibrate for 5 min before measuring the dial reading using a $\mathrm{T}$ D spindle at 10, 20,30,50,60,100 rpm. At each speed, the corresponding dial reading on the viscometer was noted. The spindle speed was successively lowered and the corresponding dial reading was noted. The measurements were carried in triplicate at ambient temperature. Direct multiplication of the dial readings with factors given in the Brookfield viscometer catalogue gave the viscosity in centipoises. Average of three triplicates was computed.

4. Stability Study: Stability study was performed as per ICH guideline. The purpose of stability testing is to provide evidence on how the quality of a drug substance or drug product varies with time under the influence of a variety of environmental factors such as temperature, humidity and light. Therefore, stability studies provide data to justify the storage condition and shelf-life of the drug product. For drug substance, such studies establish the retest date in addition to the storage condition of raw material. Stability studies were performed for selected formulation with $25 \pm 2^{\circ} \mathrm{C}$ and $60 \pm$ $5 \% \mathrm{RH}$ and $40 \pm 2^{\circ} \mathrm{C}$ and $75 \pm 5 \% \mathrm{RH}$ conditions for 6 months. The samples were analyzed at 0,3and 6-months interval for colour, physical appearance and $\mathrm{pH}$.

5. Irritancy test: Test Mark an area (1sq.cm) on the left-hand dorsal surface. The cream was applied to the specified area and time was noted. Irritancy, erythema, edema, was checked if any for regular intervals up to $24 \mathrm{hrs}$. and reported. ${ }^{[7]}$ 


\section{Evaluation of mosquito repellent activity:}

\section{Screened Cage Method}

The screened cage bioassay method employs a $40 \mathrm{~cm}$ glass-frame cage with a wooden bottom, screened top and back, clear acrylic sides (for viewing), and a front stockinette sleeve for access. 7-8-day-old female mosquitoes are placed in the cage $1 \mathrm{~h}$ before the test. The treated forearm is inserted into the cage (a glove is used to protect the hand from mosquito bites.) and the number of mosquitoes that land and probe the skin in $3 \mathrm{~min}$ is observed and recorded. observations are repeated every 30 or $60 \mathrm{~min}$.

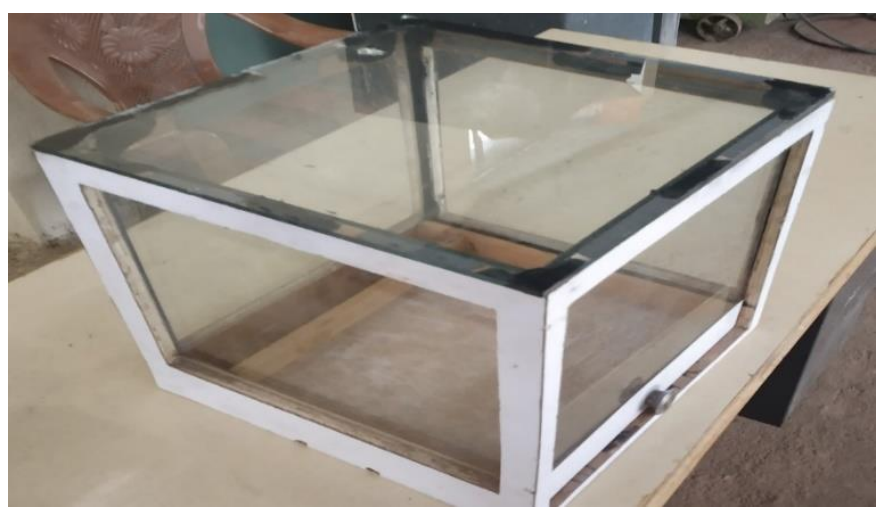

Fig no.2 Evaluation by cage method

\section{Result : (Evaluation result of extract oil)}

1. F.T.I.R: IR spectrum of carom seed oil shows characteristic peaks at

$3551.59,2960.38,1453.58,810.72$

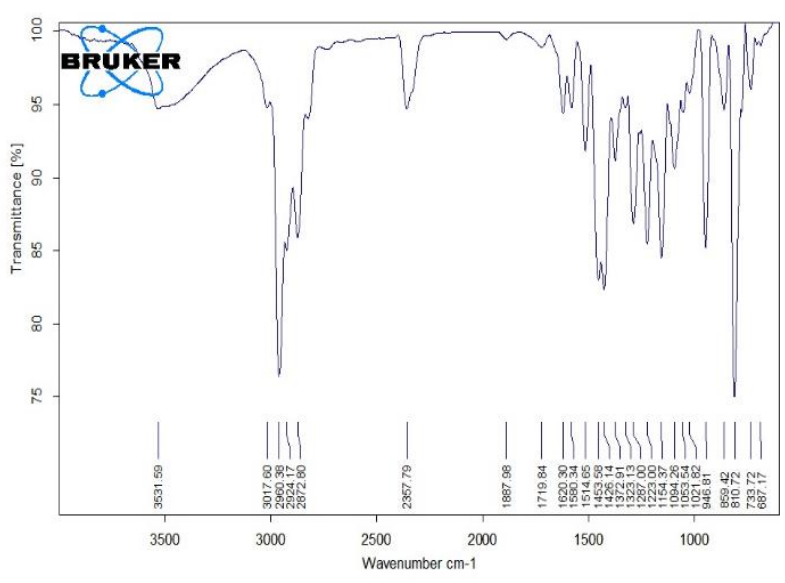

FT-IR spectrum of carrom oil

Table No.3: FT-IR results of Carrom oil

\begin{tabular}{|c|c|c|c|}
\hline Sr.no & Bond & $\begin{array}{c}\text { functional } \\
\text { group }\end{array}$ & frequency \\
\hline 1 & O-H stretch & Phenol & 3551.59 \\
\hline 2 & C-H stretch & Aromatic ring & 2960.38 \\
\hline 3 & C-C stretch & Aromatic ring & 1453.58 \\
\hline 4 & $\begin{array}{c}\text { C-H } \\
\text { substituted }\end{array}$ & $\begin{array}{c}\text { Meta } \\
\text { disubstituted } \\
\text { aromatic }\end{array}$ & 810.72 \\
\hline
\end{tabular}

Gas Chromatography- Mass Spectroscopy (GC-MS): Gas chromatography- Mass spectroscopy of carom seed oil shows characteristic peaks at 4.93,5.33,5.69,8.65.

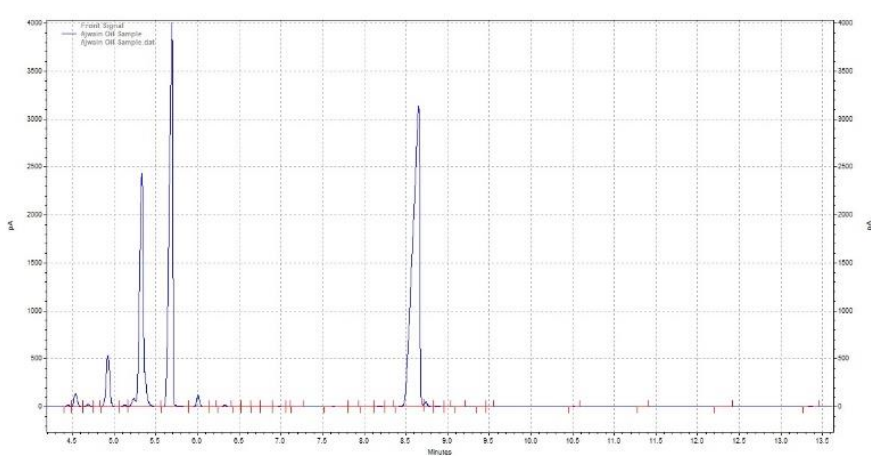

Fig. no.14: Gas chromatography- Mass spectroscopy of carom seed oil. 
Table No. 4 : GC results of carrom oil

\begin{tabular}{|c|c|c|}
\hline Sr.No. & RT (min) & Constituent \\
\hline 1. & 4.93 & $\beta$-pinene \\
\hline 2. & 5.33 & p-cymene \\
\hline 3. & 5.69 & $\gamma$-terpinene \\
\hline 4. & 8.65 & thymol \\
\hline
\end{tabular}

Result : (Evaluation result of formulation)

$\mathrm{pH}$ :

$\mathrm{pH}$ of all the formulations were found to be between $6.20 \pm 0.185$ to $6.24 \pm 0.158$ that is within the range, which are presented in the table. Although alkaline, this $\mathrm{pH}$ is typical of creams acceptable by the all standards.

Table No.5 : Result of $\mathrm{pH}$ for all formulation

\begin{tabular}{|c|c|}
\hline Formulation no. & $\mathrm{pH}($ mean \pm SD $)$ \\
\hline F 1 & $6.22 \pm 0.152$ \\
\hline F 2 & $6.20 \pm 0.189$ \\
\hline F 3 & $6.23 \pm 0.196$ \\
\hline
\end{tabular}

\section{Washability:}

The washability of all formulations was determined and it was observed that all formulation shows good washability.

Table No. 6: Result of Washability for all formulation

\begin{tabular}{|c|c|}
\hline Formulation no. & Washability \\
\hline F 1 & Good \\
\hline F 2 & Good \\
\hline F 3 & Good \\
\hline
\end{tabular}

\section{Extrudability:}

The extrudability of all formulations was determined and it was observed that all formulation shows good extrudability. The extrudability of all formulation was carried out in percentage (\%) and formulation F3 has greater extrudability as compared to other formulations.

Table No. 7: Result of Extrudability for all formulation

\begin{tabular}{|c|c|}
\hline Formulation no. & Extrudability (\%) \\
\hline F 1 & 70.42 \\
\hline F 2 & 74.33 \\
\hline F 3 & 79.45 \\
\hline
\end{tabular}

\section{Determination of viscosity:}

Viscosities of all the formulations were noted and found in the range of $2545 \pm 7.83$ to $3597 \pm 7.25$ CPS at $10 \mathrm{rpm}$ as shown in table. All the formulations were showed pseudo plastic flow.

Table No.8: Result of viscosity for all formulation

\begin{tabular}{|c|c|}
\hline Formulation no. & $\begin{array}{c}\text { Viscosity at 10 rpm (CPS) } \\
\text { (mean } \pm \text { SD) }\end{array}$ \\
\hline F 1 & $2545 \pm 7.83$ \\
\hline F 2 & $3225 \pm 7.22$ \\
\hline F 3 & $3597 \pm 7.25$ \\
\hline
\end{tabular}

\section{Irritancy test:}

The irritancy test of all formulations was determined and it was observed for Irritancy, erythema, edema. All the formulation does not show any Irritancy, erythema, edema.

\section{Conclusion}

The formulation containing 7.5\% of Carom seed oil extract showed repellent activity up to $80 \%$ these results are encouraging and promising. At last it was concluded that carom seed oil extract has potential of 
mosquito repellent and can be converted into a marketed formulation like essence stick, repellent cream etc.

\section{ACKNOWLEDGMENTS}

Authors are thankful to Prof. Dr. B. P. Ronge Secretary, SVERI's College of Pharmacy, Gopalpur, Pandharpur for providing necessary facilities to carry out this work. his valuable moral support.

\section{REFERENCES}

[1]. S. D. Chavare et,al. "Formulation of Novel Herbal Mosquito Repellent: A New Approach in Antimalarial Management" IJMOR Vol.01, No.02, pp 78-85, 2015.

[2]. EK. Patel et,al. a review on: mosquito repellent methods IJPCBS 2012, 2(3), 310-317.

[3]. Rafal Abdul Hussein Extraction of Essential Oils from Some Types of Umbelifera Family using Microwave-Assisted Water Distillation Journal of Biology, Agriculture and Healthcare Vol.5, No.22, 2015.

[4]. MD. Mazher ahmed Topixal gel formulation: A review JPQA Volume 2 Issue 1 August, 2016.

[5]. Basch E, Bent S, Foppa I, Haskmi S, Kroll D, Mele M, Szapary P, Ulbricht C, Vora M, Yong S. Marigold (Calendula officinalis L.): An evidencebased systematic review by the Natural Standard Research Collaboration. J. Herb. Pharmacother. 2006, 6(3-4),135-159.Mukherjee et al., Collection, extraction, evaluation of Physicochemical parameters and characterization of Calendula oil.

[6]. Saisugun J, Extraction and biological evaluation of esterfied lutein from marigold flower petals IJCS Volume 1; Issue 1; September 2017; Page No. 14-22.

[7]. Ruchi S. Shivhare, Development of mosquito repellant gel formulations from various natural volatile oils: comparative study with the marketed formulation odomos JDDT ISSN: 22501177, 2018.

[8]. Sinka ME, Bangs MJ, Manguin S, Rubio-Palis Y, Chareonviriyaphap $\mathrm{T}$, Coetzee $\mathrm{M}$, Mbogo CM, Hemingway J, Patil AP, Temperley WH, Gething PW. A global map of dominant malaria vectors. Parasite Vect 2012; 5(1):69.

[9]. Mahapatra DK, Bharti SK, Asati V. Chalcone scaffolds as anti-infective agents: Structural and molecular target perspectives. Eur J Med Chem 2015; 101:496-524.

[10]. Guillet P, Alnwick D, Cham MK, Neira M, Zaim M, Heymann D, Mukelabai K. Long-lasting treated mosquito nets: a breakthrough in malaria prevention. Bull World Health Org, 2001; 79(10):998.

[11]. Girard MP, Reed ZH, Friede M, Kieny MP. A review of human vaccine research and development: malaria. Vaccine, 2007; 25(9):1567-1580.

[12]. Roberts DR, Alecrim WD, Hshieh P, Grieco JP, Bangs M, Andre RG, Chareonviriphap T. A probability model of vector behavior: effects of DDT repellency, irritancy, and toxicity in malaria control. J Vect Ecol, 2000; 25(1):48-61.

\section{Cite this article as :}

Nikam Mangesh Maruti, More V.V., "Design and Development of Mosquito Repellent Formulation Containing Carom Seed", International Journal of Scientific Research in Science and Technology (IJSRST), Online ISSN : 2395-602X, Print ISSN : 23956011, Volume 7 Issue 5, pp. 88-94, SeptemberOctober 2020. Available at doi : https://doi.org/10.32628/IJSRST207520 Journal URL : http://ijsrst.com/IJSRST207520 